\title{
Design and Simulation of MPPT Control for Solar Powered AC Autonomous LED Lighting Applications in MATLAB/Simulink Environment
}

\author{
P. Ramesh Babu, C. Krishnakumar, S. Kiruthiga
}

\begin{abstract}
As an AC LED light applications have become a commonplace item of light industry, it has a wide range of usage in garden lighting, cove lighting, office lighting and retail applications. The paper brings out the utilization of Boost converter along with Maximum Power Point Tracker (MPPT) technique for the control of Photovoltaic power. This proposed system which includes Boost converter, a single phase full bridge inverter with Sinusoidal Pulse Width Modulation (SPWM) technique. The main concept of this converter includes designing of boost converter that provides an output voltage of $350 \mathrm{~V} \mathrm{DC}$ and single phase SPWM provides $350 \mathrm{~V}$, pure sine wave output $(230 \mathrm{~V}$ RMS) applicable to AC autonomous LED Lighting system. In order to bring out a transformer free inverter, the designed boost converter is simulated in the MATLAB Simulink software and the results are shown with low THD as per IEEE standard, with acceptable power factor and higher efficiency.
\end{abstract}

Keywords: MPPT; Perturb and Observe Algorithm; Boost converter; Inverter, SPWM.

\section{INTRODUCTION}

Industrial and Domestic energy production widely depends on a limited resource. Energy usage is playing an important role in day today's life. As electricity can be generated by burning the fossil fuels which leads to major drawback of severe/drastic climatic changes such as acid rain, global warming etc.,

In order to overcome these drawbacks, solar energy is widely used as the major source of energy for the generation of electrical energy from the photovoltaic array [5].

The step up or step down transformer used for the conversion of voltage in traditional inverters faces major drawbacks of its large size, higher total harmonic distortion and being high-priced.

Revised Manuscript Received on March 17, 2020.

* Correspondence Author

P.Ramesh Babu*, Assistant Professor in the department of EEE in Saranathan College of Engineering, Trichy.

Dr.C.Krishnakumar, Professor/Head in the department of EEE in Saranathan College of Engineering, Trichy.

S.Kiruthiga, PG Scholar in the department of Power Electronics and Drives in Saranathan College of Engineering, Trichy.

(c) The Authors. Published by Blue Eyes Intelligence Engineering and Sciences Publication (BEIESP). This is an open access article under the CC BY-NC-ND license (http://creativecommons.org/licenses/by-nc-nd/4.0/)
These disadvantages are eliminated in this paper by introducing a single stage step up converter, to form a compact, inexpensive transformer free inverter. Maximum power point tracking (MPPT) mechanism is used for the extraction of maximum possible power using

the Perturb and Observe algorithm from the PV array, which is considered as the most popular conventional method for capturing the required maximum power. This proposed system brings out a transformer less inverter which supports the benefits of having reduced size, compact, less priced and with low Total Harmonic Distortion (THD). Sinusoidal Pulse Width Modulation (SPWM) is generated by comparing the reference signal along with the triangular carrier wave and used for gating purpose in an inverter [12]. Finally, the proposed system is designed mathematically and simulated in MATLAB/Simulink software to verify the performance of various subsystems.

\section{BLOCK REPRESENTATION OF PROPOSED MPPT SYSTEM}

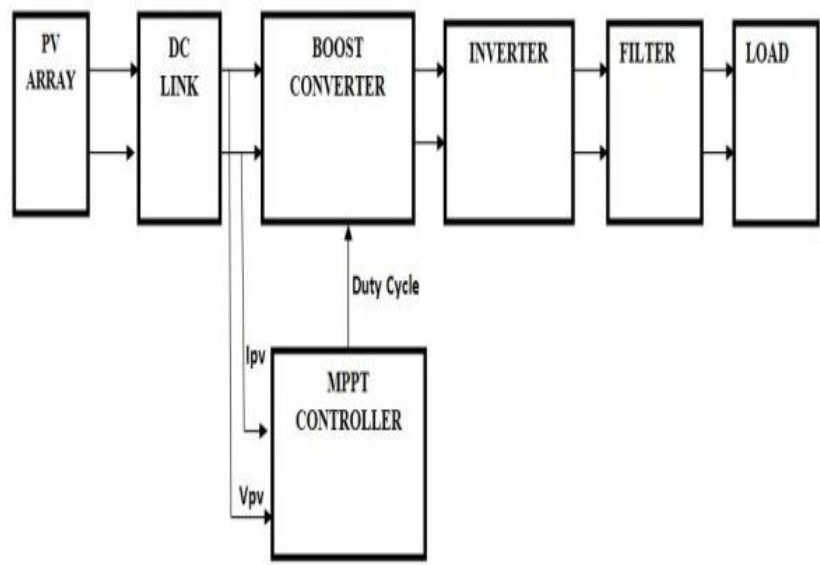

Fig.1. Block representation of MPPT configuration PV cells or arrays are the power source of the system, which are modeled by an equivalent circuit and simulated to show the exact behavior of a PV array. Then, the two power converters are used for the control of,

1) Extracting maximum power

2) Deliver of power to AC grid with an acceptable THD and Power Factor.

\section{Published By:}

Blue Eyes Intelligence Engineering \& Sciences Publication

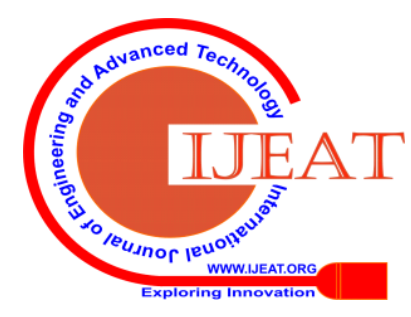


A PWM Generator block, which can generate pulse width modulated (PWM) signals with a variable duty cycle was built by using Simulink model.

Calculation of duty cycle for step up converter uses the sensed PV array voltage and current using MPPT control algorithm. Step by step verification of various blocks includes multiple subsystems. The irradiance and temperature condition was changed using the irradiance block. The performance of single phase SPWM inverter system is validated and the results are provided at the end.

\section{DESIGN OF BOOST CONVERTER}

A boost converter converts the output voltage higher than that to the corresponding input voltage. This section illustrates the conversion of $150 \mathrm{~V}$ input voltage of PV array to $350 \mathrm{~V}$ (230V RMS) output voltage connected to AC LED applications [5].

\section{A. Operation of step up Converter}

The step up converter undergoes two modes of operation with respect to the closing and opening of the power MOSFET. (1)Charging mode, (2) Discharging mode [12]. The following equation (1) represents the switch S during ON state,

$$
V_{\text {in }}=L_{\text {ind }} \frac{I_{2}-I_{1}}{t_{1}}
$$

Equation (2) represents the switch (S) during OFF state,

$$
V_{\text {in }}-V_{o}=L_{\text {ind }} \frac{I_{1}-I_{2}}{t_{2}}
$$

\section{B. Design Characteristics}

The designed characteristics of step up converter is given in table I.

Table I

Designed Characteristics Of Boost Converetr

\begin{tabular}{|l|c|c|}
\hline PARAMETERS & SYMBOL & VALUE \\
\hline SOURCE VOLTAGE & $V_{\text {in }}$ & $150 \mathrm{~V}$ \\
\hline OUTPUT VOLTAGE & $V_{\text {out }}$ & $350 \mathrm{~V}$ \\
\hline INPUT POWER & $\mathrm{P}_{\text {IN }}$ & $2 \mathrm{KW}$ \\
\hline SWITCHING FREQUENCY & $f_{s}$ & $25 \mathrm{KHz}$ \\
\hline
\end{tabular}

\begin{tabular}{|lc|c|c|}
\hline $\begin{array}{l}\text { INDUCTOR CURRENT } \\
\text { (RIPPLE 1\%) }\end{array}$ & $\Delta \mathrm{I}_{\mathrm{L}}$ & $0.1332 \mathrm{~A}$ \\
\hline $\begin{array}{l}\text { OUTPUT RIPPLE VOLTAGE } \\
\text { (RIPPLE 1\%) }\end{array}$ & $\Delta \mathrm{V}_{\text {OUT }}$ & $3.5 \mathrm{~V}$ \\
\hline $\begin{array}{l}\text { MAXIMUM INDUCTOR } \\
\text { CURRENT }\end{array}$ & $I_{\text {LMax }}$ & $13.32 \mathrm{~A}$ \\
\hline $\begin{array}{l}\text { MAXIMUM OUTPUT } \\
\text { CURRENT }\end{array}$ & $\mathrm{I}_{\text {OUT }}$ & $5.714 \mathrm{~A}$ \\
\hline $\begin{array}{l}\text { INDUCTOR } \\
\text { CAPACITOR }\end{array}$ & $\mathrm{L}$ & $26 \mathrm{MH}$ \\
\hline
\end{tabular}

\section{Duty cycle}

The Duty ratio is determined by,

$$
D=1-\frac{V_{\text {in }}}{V_{\text {rut }}}
$$

The load resistance is determined by,

$$
R=\frac{V_{O}{ }^{2}}{P}
$$

Average inductor current is determined by,

$$
I_{L}=\frac{V_{O} * I_{O}}{V_{i n}}
$$

The variation of inductor current to meet $1 \%$ specifications is then,

$\Delta i_{L}=1 \%\left(I_{L}\right)$

D. Inductor selection

$L=\frac{V_{i n} * D}{\Delta \mathrm{I}_{\mathrm{L}} * \mathrm{f}_{\mathrm{s}}}$

\section{E. Capacitor Selection}

$C=\frac{D}{R\left(\frac{A V_{\text {out }}}{V_{\text {out }}}\right) f_{x}}$

\section{F. Simulation Design of Boost Converter}

The designed simulation circuit of boost (step up) converter is illustrated below in Fig.2.

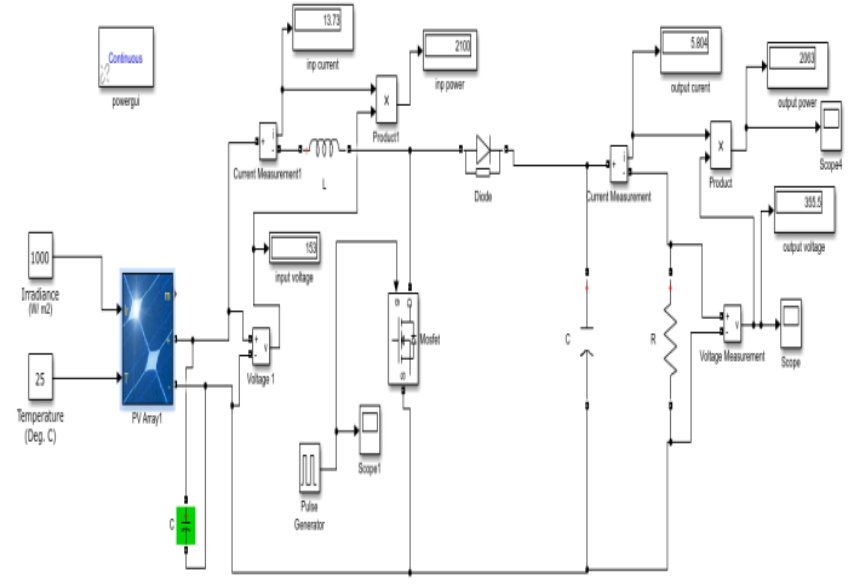

Fig.2. MATLAB/Simulink model of boost converter

\section{G. Simulation Output of Boost Converter}

The simulated (output) voltage, current, and power of step up converter is illustrated in Fig.3, Fig.4 \& Fig.5. Thus boost converter converts the given $150 \mathrm{~V}$ unregulated voltage to $350 \mathrm{~V}$ regulated voltage.

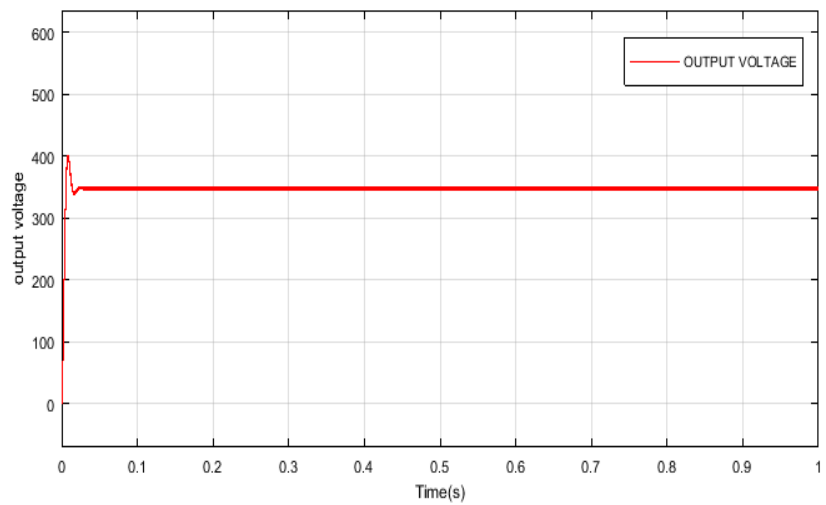

Fig.3. Simulated output voltage of step up converter

Published By:

Blue Eyes Intelligence Engineering

\& Sciences Publication 


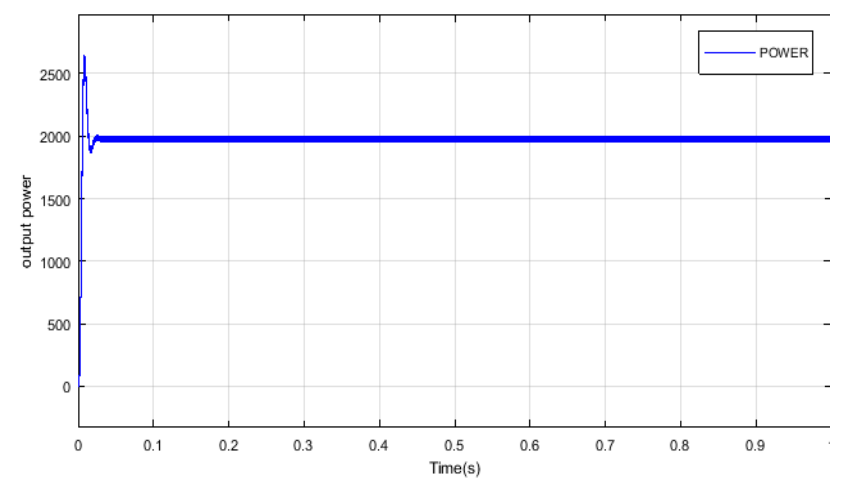

Fig.4. Simulated output power of step up converter

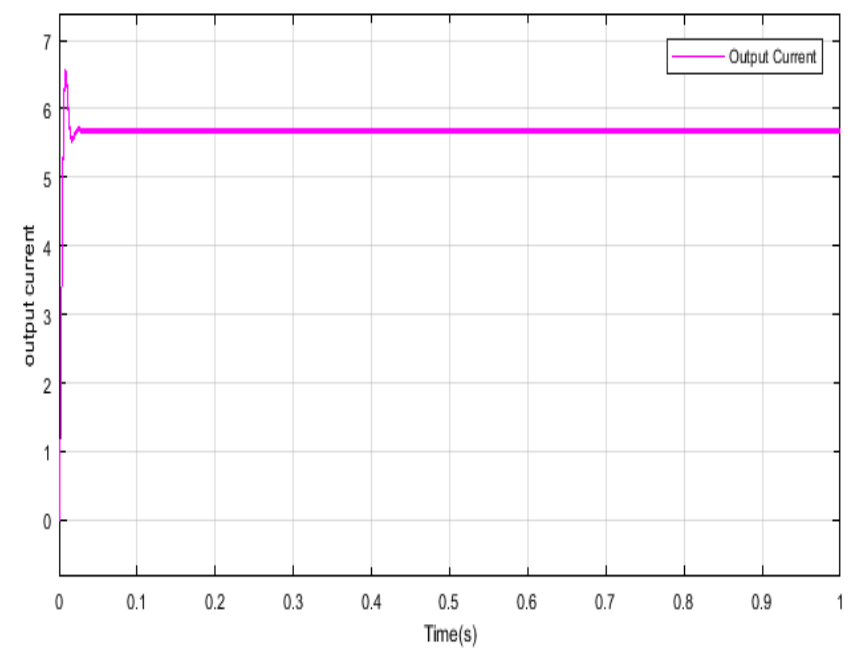

Fig.5. Simulated output current of step up converter

\section{MAXIMUM POWER POINT TRACKING (MPPT)}

Maximum power point tracking technique is based on impedance matching between PV module and load which uses an algorithm and electrical circuitry for maximum power transfer. The most common algorithm is the Perturb and Observe method which uses the recorded values of voltage and current values of PV array to obtain the power. These corresponding values are perturbed to extract the maximum power so that the operating point reaches maximum power point on the slope of $\mathrm{P}-\mathrm{V}$ characteristics. The algorithmic expressions are given in equation (9), (10) \& (11).

$\frac{\partial P_{P V}}{\partial V_{P V}}>0=d=(d+\Delta d)($ i.e., increment $d)$

$\frac{\partial P_{P V}}{\partial V_{P V}}<0=d=(d-\Delta d)($ i.e., decrement $d)$

At MPP, $\frac{\partial P_{P V}}{\partial V_{P V}}=d=d$ or $\Delta d($ i.e., retain $d)$

\section{A. PV array characteristics}

The PV array electrical characteristics is illustrated in table II

\section{Table Ii}

Pv Array Electrical Characteristics

\begin{tabular}{|l|c|}
\hline MAXIMUM RATED POWER $\left(\mathrm{P}_{\mathrm{MAX}}\right)$ & $60 \mathrm{WP} \pm 3 \%$ \\
\hline OPEN CIRCUIT VOLTAGE $\left(\mathrm{V}_{\mathrm{OC}}\right)$ & $21.24 \mathrm{~V}$ \\
\hline SHORT CIRCUIT VOLTAGE $\left(\mathrm{I}_{\mathrm{SC}}\right)$ & $3.55 \mathrm{~A}$ \\
\hline VOLTAGE AT MAX POWER $\left(\mathrm{V}_{\mathrm{MP}}\right)$ & $17.64 \mathrm{~V}$ \\
\hline CURRENT AT MAX POWER $\left(\mathrm{I}_{\mathrm{MP}}\right)$ & $3.40 \mathrm{~A}$ \\
\hline SYSTEM VOLTAGE & $600 \mathrm{VMAX}$ \\
\hline TEMP COEFFICIENT OF $\mathrm{I}_{\mathrm{SC}}$ & $0.05 \mathrm{~A}$ \\
\hline TEMP COEFFICIENT OF $\mathrm{V}_{\mathrm{OC}}$ & $-0.35 \mathrm{~V}$ \\
\hline NO. OF CELL IN PARALLEL STRINGS & 5 \\
\hline
\end{tabular}

\section{B. P-V array characteristic curve}

The P-V characteristic curve for power v/s temperature and current v/s temperature is shown in Fig.6 \& Fig.7.

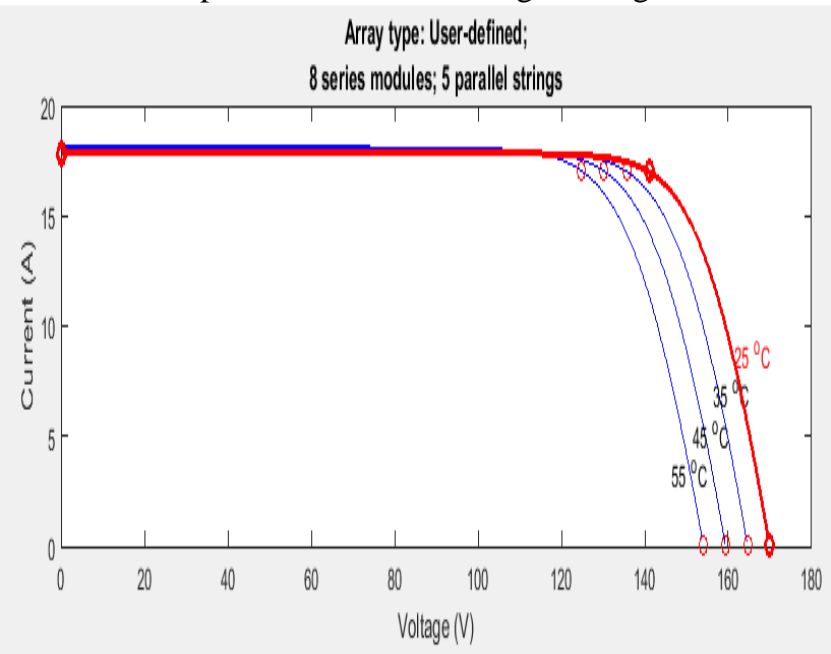

Fig.6.voltage versus current with different temperature levels

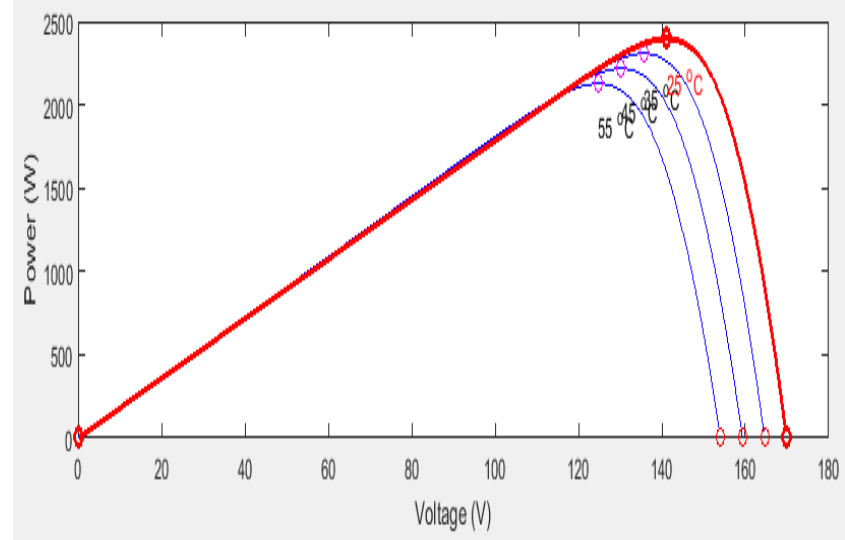

Fig.7. Power versus voltage with different temperature levels

\section{Perturb and Observe algorithm}

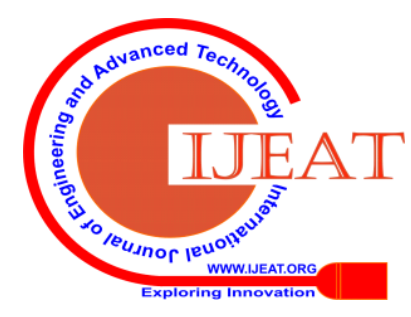


Design and Simulation of MPPT control for Solar Powered AC Autonomous LED Lighting Applications in MATLAB/Simulink Environment

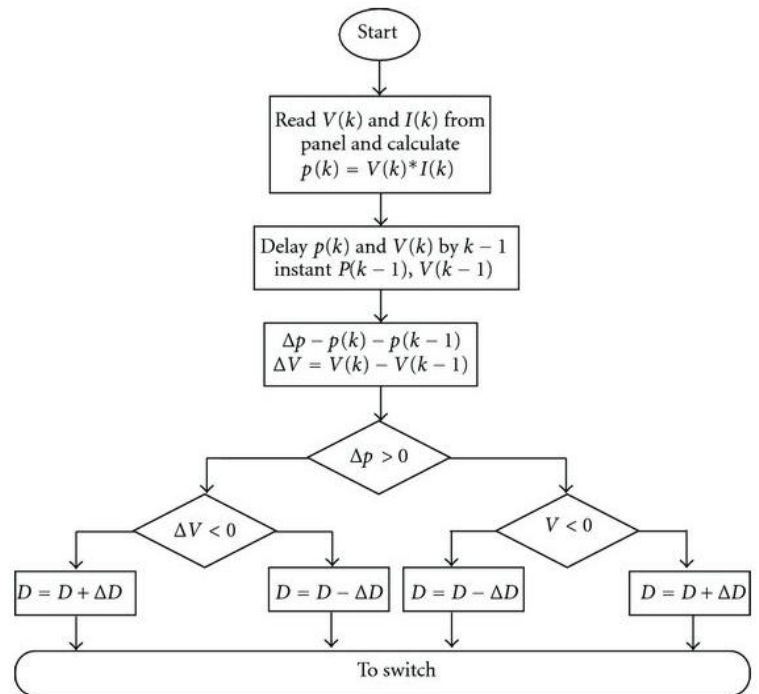

Fig.8. Flow chart of Perturb and Observe algorithm

D. Simulation model of MPPT system

The simulated circuit of MPPT using Perturb and Observe method is shown is given in below Fig.9.

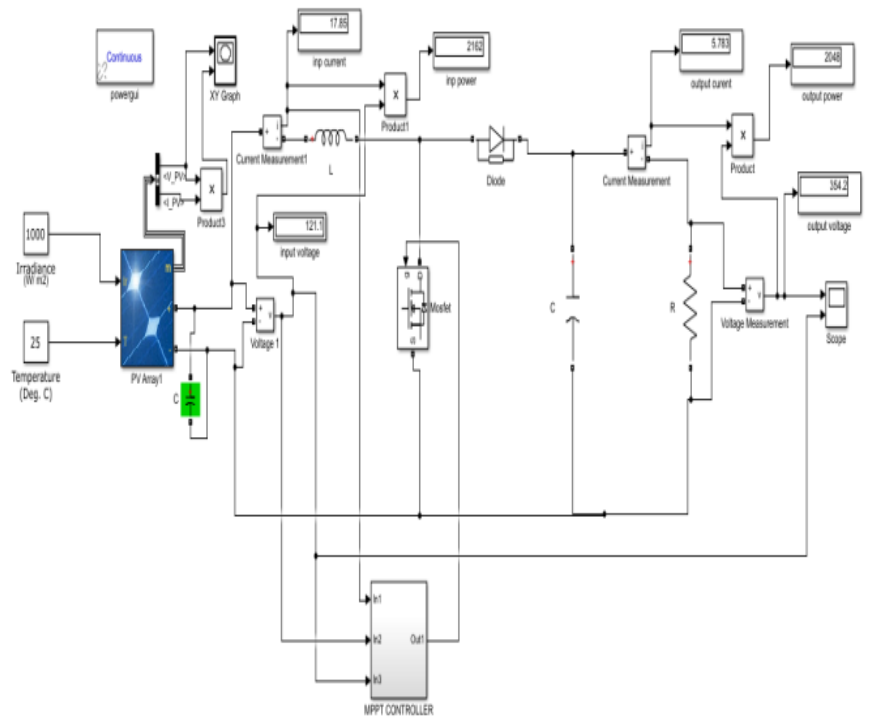

Fig.9. Simulated model of MPPT by P\&O algorithm

\section{E. Simulation results}

The simulation results of MPPT system using P\&O algorithm is shown in given Fig10, Fig.11 and Fig 12.

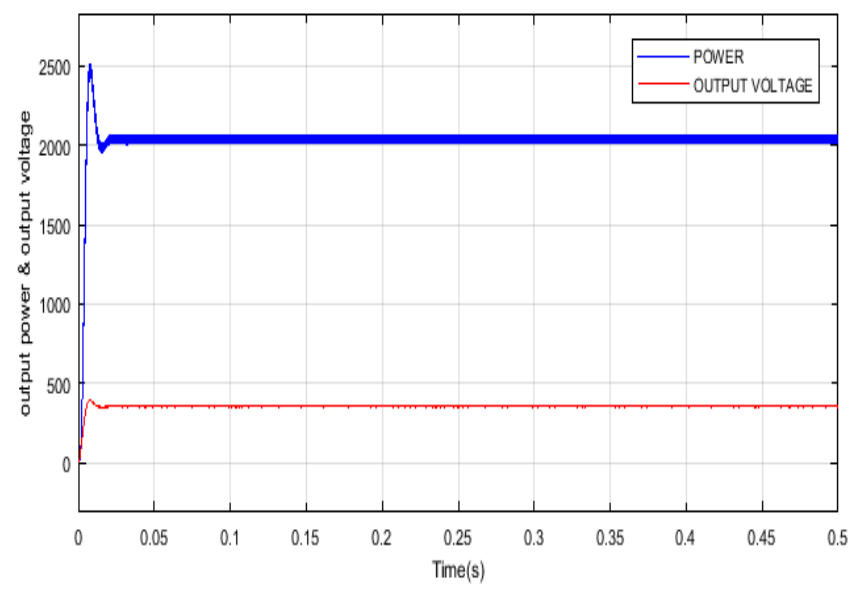

Fig.10. Simulated output power and output voltages of MPPT system

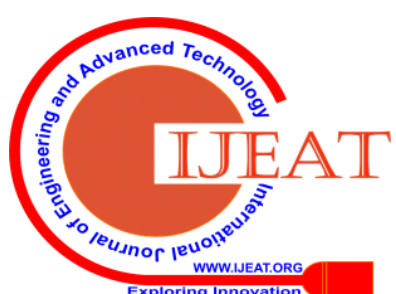


The reference signal $F_{r}$, is compared with triangular carrier wave $f_{c}$, to generate the corresponding gating signals. Fig.14 shows the generation of SPWM,

$$
V_{o}=V_{s} \sqrt{\frac{p \partial}{\pi}}=V_{s} \sqrt{\sum_{m-1}^{2 p} \frac{\partial_{m}}{\pi}}
$$

\section{A. Simulation model of SPWM inverter}

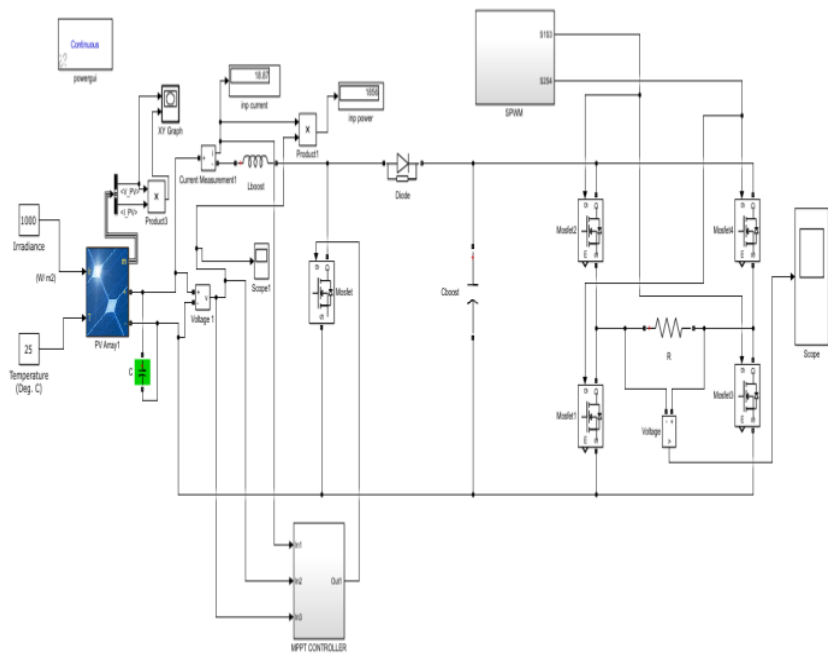

Fig.14. MATLAB/Simulink model of SPWM inverter

\section{B. Simulation result of SPWM generation}

The gate pulses (both on and off cycles) are generated for the inverter as shown in Fig.16 and Fig.17.

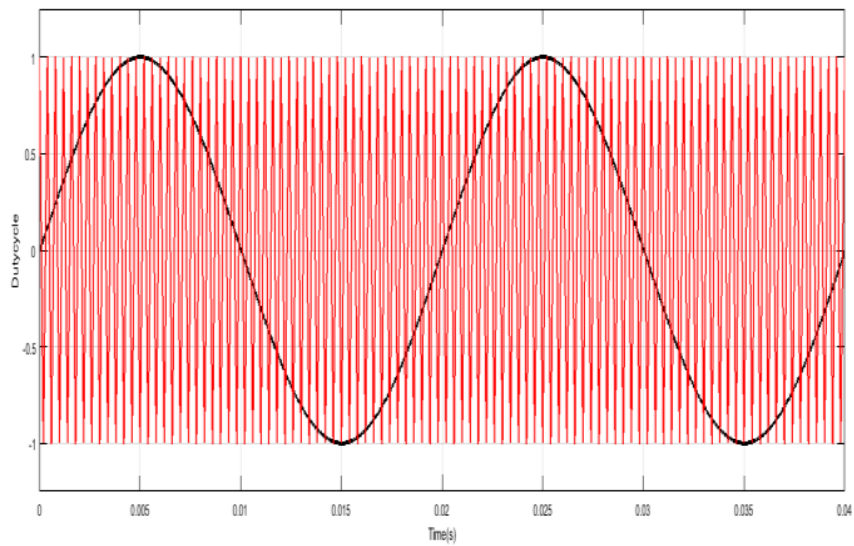

Fig.15. Carrier wave signal compared with reference wave signal

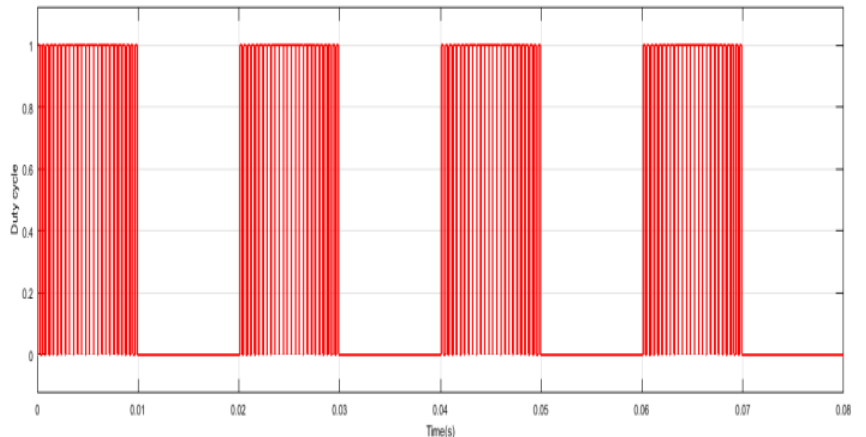

Fig.16. Positive (ON) cycle of SPWM

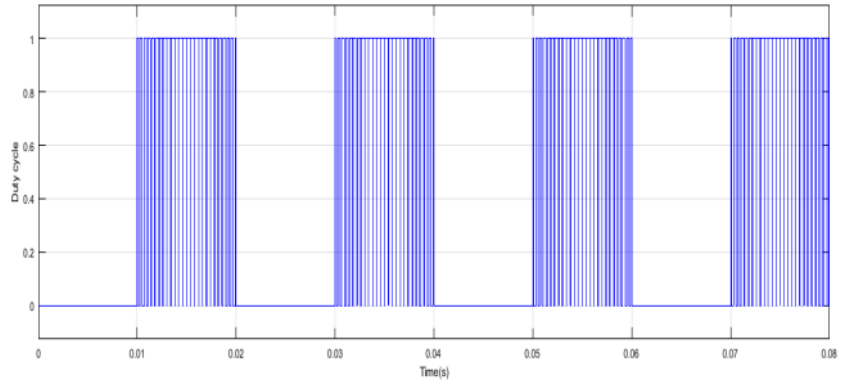

Fig.17. Negative (OFF) cycle of SPWM

\section{APPLICATION OF BOOST CONVERTER TO SINGLE PHASE INVERTER}

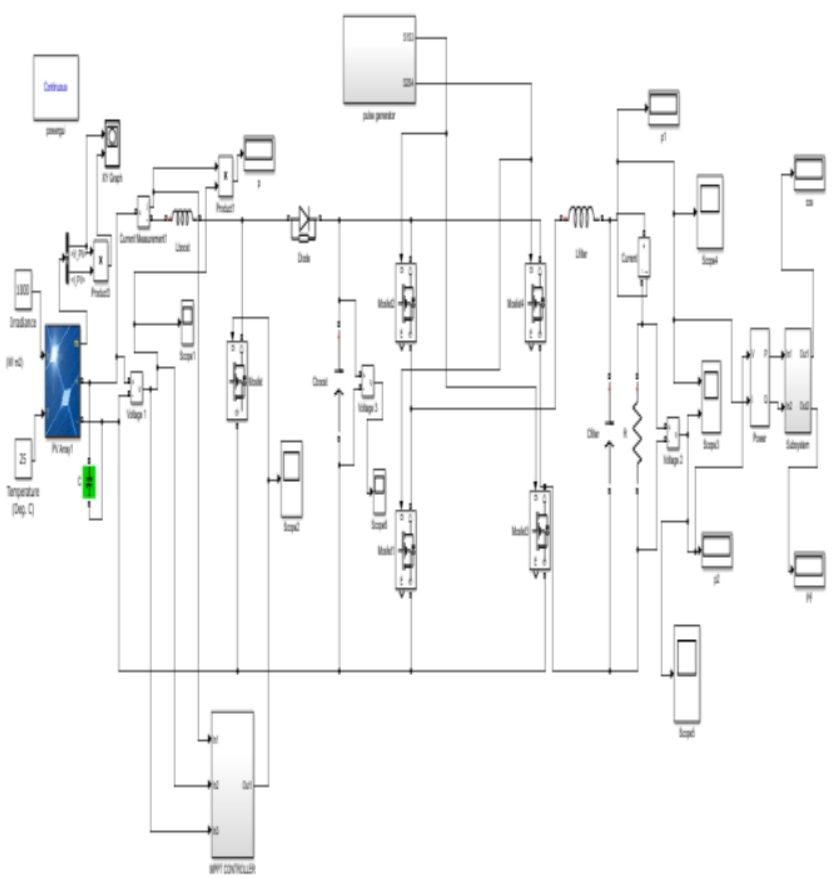

Fig.18. MATLAB/Simulink representation of single phase inverter circuit using Boost converter

\section{A. LC filter design}

The LC filter of an inverter is designed using 1) Selecting switching frequency 2) selecting $\mathrm{K}$ factor 3) Selecting $\alpha$ factor.

According to DC and AC voltage of the inverter, 0.95 is acceptable for modulation factor. To limit inductor ripple current below $40 \%, \alpha$ factor should be more than 0.025 at $\mathrm{f}_{\mathrm{s}}=25 \mathrm{KHz}$ [1]. This aims the filter specification which is listed in table-IV.

The formula for LC low pass filter calculation is,

$\frac{V_{\text {out }}}{V_{\text {in }}}=\frac{1}{1-\omega^{2} L C}$

Where, $\omega=2 \pi f$

The cutoff frequency for an LC filter is,

$f_{c}=\frac{1}{2 \pi \sqrt{L C}}$

Table Iv

Design Specfication Of Lc Filter

\begin{tabular}{|c|c|}
\hline $\mathrm{L}$ & $260 \mathrm{MH}$ \\
\hline $\mathrm{C}$ & $26.21 \mu \mathrm{F}$ \\
\hline
\end{tabular}

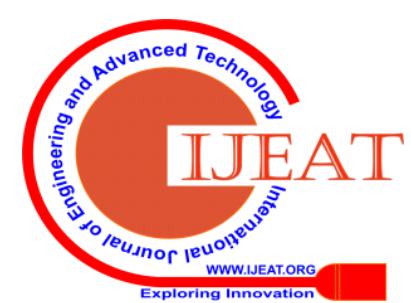




\begin{tabular}{|c|c|}
\hline$f_{s}$ & $25 \mathrm{KHz}$ \\
\hline$f_{1}$ & $50 \mathrm{~Hz}$ \\
\hline
\end{tabular}

\section{B. Power Factor Correction (PFC)}

Power Factor (PF) may be a measurement by which we will measure the efficiency of the electrical equipment's also as AC electric power system on the idea of electricity consumption [5]. It is the technique to compensate the unwanted effects of reactive loads that make the facility factor but unity.

Power Factor $=\frac{\text { True Power }}{\text { Apparent } \text { Power }}=\frac{P}{S}$

$$
\begin{aligned}
& P F_{\text {Displacement }}(D P F)=\cos \phi \\
& P F_{\text {Distortion }}(D F)=\frac{I_{1 \text { rms }}}{I_{\text {rms }}}=\frac{1}{\sqrt{1+(T H D)^{2}}}
\end{aligned}
$$

True PF $=$ Displacement $\mathrm{PF} *$ Distortion PF

$\mathrm{PF}=\frac{\cos \emptyset}{\sqrt{1+(T H D)^{2}}}$

\section{Simulation block of Power Factor}

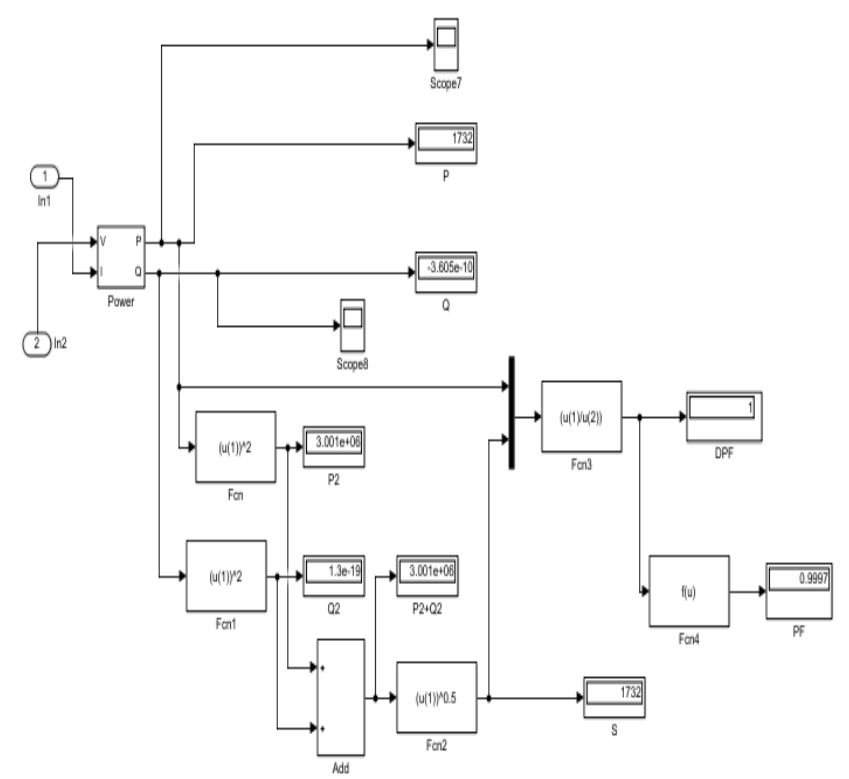

Fig.19. Power factor simulation block

\section{Inverter Output Voltage and Current}

The simulated non-sinusoidal output voltage waveform is given in Fig.20, is distorted and contains excessive harmonics.

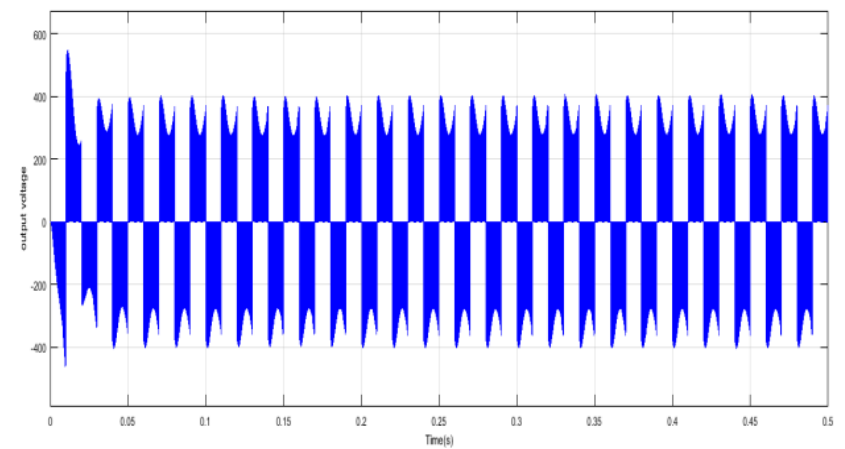

Fig.20. Output voltage waveform without using filter

In order of eliminating the harmonics, the inverter uses a LC filter for the reduction of harmonics. Therefore the obtained result is a $350 \mathrm{~V}$ (AC peak voltage), $230 \mathrm{~V}$ RMS is given in Fig.23.

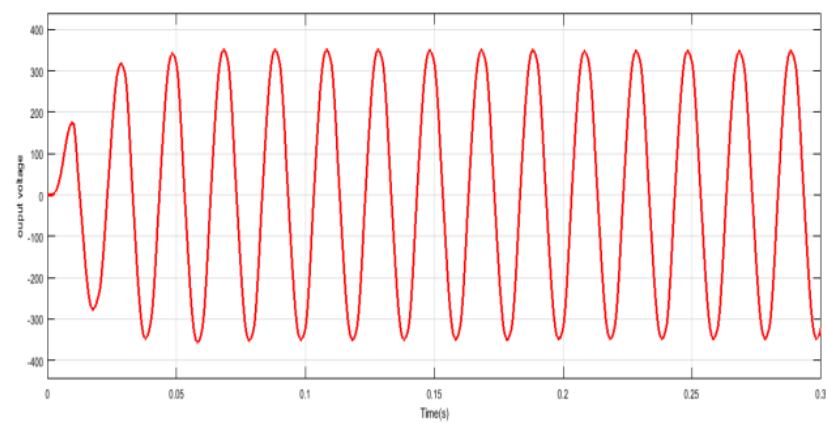

Fig.21. Simulated Inverter voltage waveform with filter

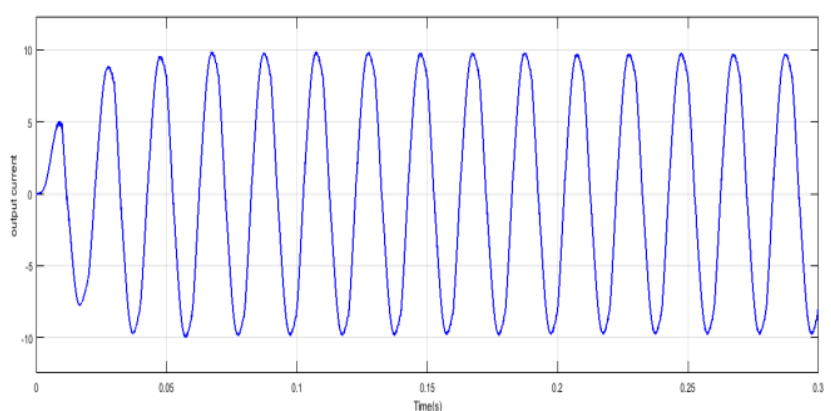

Fig.22. Simulated Inverter current waveform with filter

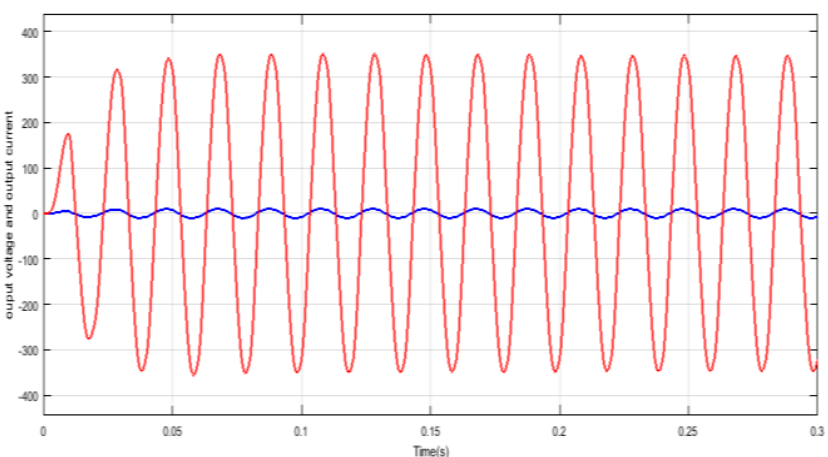

Fig.23. Simulated output voltage in-phase with output current

The performance of the designed inverter is tested by applying with and without LC filter in the MATLAB/ Simulink using the measured load current. Table-V describes FFT \& THD analysis (with and without filter) of output voltage and power factor performances.

Table V

\begin{tabular}{|c|c|c|c|c|}
\hline $\begin{array}{c}\text { VOLTAGE } \\
\text { THD } \\
\text { IN } \\
\% \\
\text { (WITHOUT } \\
\text { FILTER) } \\
\end{array}$ & $\begin{array}{c}\text { VOLTAGE } \\
\text { THD } \\
\text { IN } \\
\% \\
\text { (WITH } \\
\text { FILTER) } \\
\end{array}$ & $\begin{array}{c}\text { DISPLACEM } \\
\text { ENT } \\
\text { FACTOR } \\
\text { (DPF) }\end{array}$ & $\begin{array}{l}\text { DISTORTION } \\
\text { FACTOR } \\
\text { (DF) }\end{array}$ & $\begin{array}{c}\text { POWER } \\
\text { FACTOR } \\
\text { (DPF*DF) }\end{array}$ \\
\hline 67.31 & 3.53 & 0.98 & 0.9997 & 0.9797 \\
\hline
\end{tabular}

Summary Of Simulated Inverter In Matlab Software

The Total Harmonic Distortion (THD) is obtained using FFT analysis, which reviews that the inverter without filter output voltage includes harmonics of $67.31 \%$ which is above the IEEE 519 standard as shown in Fig.24

Published By:

Blue Eyes Intelligence Engineering

\& Sciences Publication

DOI: 10.35940/ijeat.C6557.049420

Journal Website: www.ijeat.org

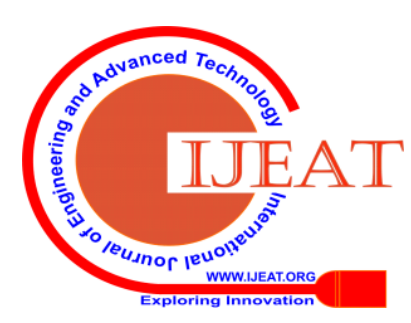




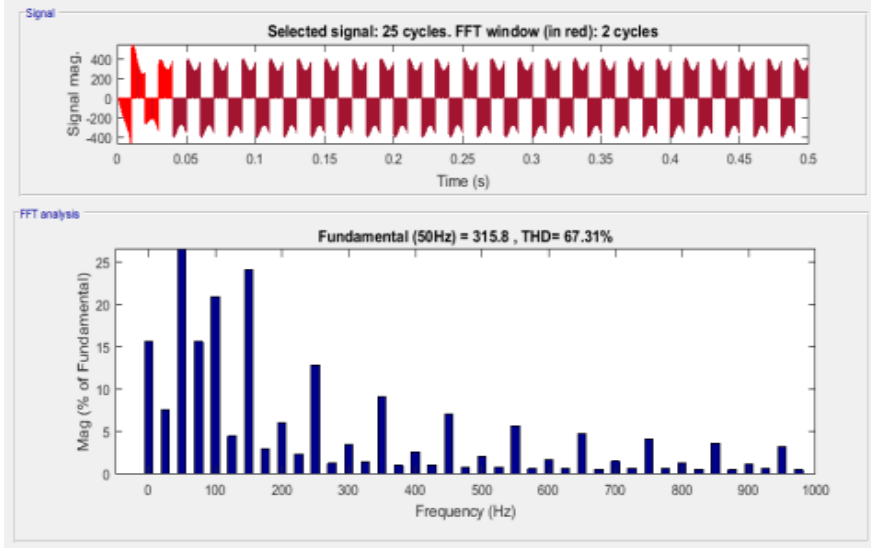

Fig.24. FFT \& THD analysis of without using filter

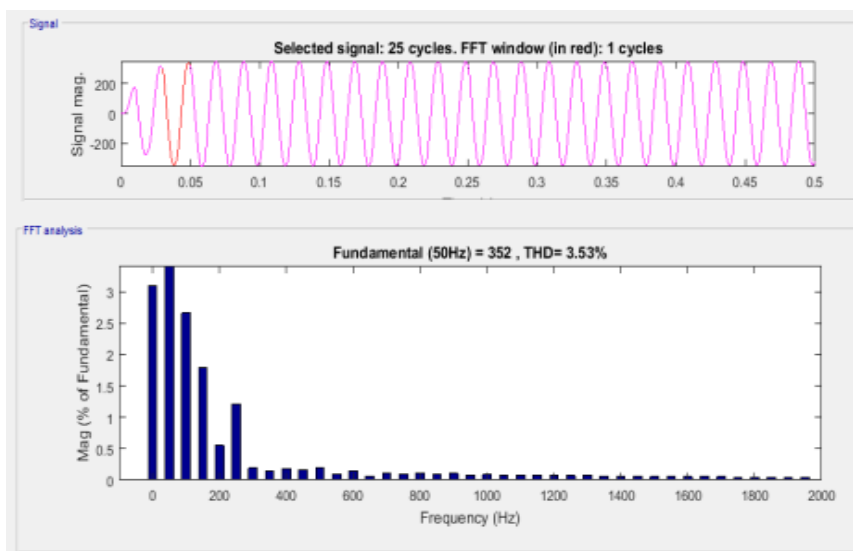

Fig.25. FFT \& THD analysis with using filter

From the above Fig.25 it is reviewed that output voltage employing LC filter has low level Total Harmonic Distortion (THD) of 3.53\% which is below the IEEE 519 standard.

\section{CONCLUSION}

This paper investigates a transformer free solar powered inverter for 230V RMS, $50 \mathrm{~Hz}$ AC Autonomous LED Lighting applications. From the simulation results, it is clearly observed that THD of the proposed system is $3.53 \%$ which is below the value stated in IEEE 519 a Standard for assessing the Harmonic levels. It is crystal clear that the Implementation of transformer free Solar powered inverter leads to good improvement in power factor and pure AC Sinusoidal wave shaping. As a future work the hardware setup for the simulation circuit will be fabricated and the results will be compared for validation.

\section{REFERENCES}

1. Ahmad, A. Ale, Adib Abrishamifar, and Mohammad Farzi. "A new design procedure for output LC filter of single phase inverters." 3rd International Conference on Power Electronics and Intelligent Transportation System. 2010.

2. Atallah, Ahmed M., Almoataz Y. Abdelaziz, and Raihan S. Jumaah. "Implementation of perturb and observe MPPT of PV system with direct control method using buck and buck-boost converters." Emerging Trends in Electrical, Electronics \& Instrumentation Engineering: An international Journal (EEIEJ) 1.1 (2014): 31-44.

3. Bahari, Mohammad Iman, et al. "Modeling and simulation of hill climbing MPPT algorithm for photovoltaic application." 2016 International Symposium on Power Electronics, Electrical Drives, Automation and Motion (SPEEDAM). IEEE, 2016.

4. Razzak. "Design of single-stage buck and boost converters for photovoltaic inverter applications." 2014 International Conference on Informatics, Electronics \& Vision (ICIEV). IEEE, 2014.

5. Chakraborty, Sajib, Wahidul Hasan, and SM Baque Billah. "Design and analysis of a transformer-less single-phase grid-tie photovoltaic inverter using boost converter with Immittance conversion topology." 2014 International Conference on Electrical Engineering and Information \& Communication Technology. IEEE, 2014.

6. Haider, Rafid, et al. "Design and construction of single phase pure sine wave inverter for photovoltaic application." 2012 International Conference on Informatics, Electronics \& Vision (ICIEV). IEEE, 2012.

7. Hasaneen, B. M., and Adel A. Elbaset Mohammed. "Design and simulation of DC/DC boost converter." 2008 12th International Middle-East Power System Conference. IEEE, 2008.

8. Kasa, Nobuyuki, and Takahiko Iida. "A transformer-less single phase inverter using a buck-boost type chopper circuit for photovoltaic power system." ICPE (ISPE) 논문집 (1998): 978-981.

9. Kwang, Tan Kheng, and Syafrudin Masri. "Single phase grid tie inverter for photovoltaic application." 2010 IEEE Conference on Sustainable Utilization and Development in Engineering and Technology. IEEE, 2010.

10. Li, Sheng-qing, et al. "A new MPPT control method of photovoltaic grid-connected inverter system." The 26th Chinese Control and Decision Conference (2014 CCDC). IEEE, 2014.

11. Peftitsis, Dimosthenis, Georgios Adamidis, and Anastasios Balouktsis. "A new MPPT method for Photovoltaic generation systems based on Hill Climbing algorithm." 2008 18th International Conference on Electrical Machines. IEEE, 2008.

12. Rashid, Muhammad H., ed. Power electronics handbook. Butterworth-Heinemann, 2017

13. Wang, Chien-Ming. "A novel single-stage full-bridge buck-boost inverter." Eighteenth Annual IEEE Applied Power Electronics Conference and Exposition, 2003. APEC'03.. Vol. 1. IEEE, 2003.

\section{AUTHORS PROFILE}

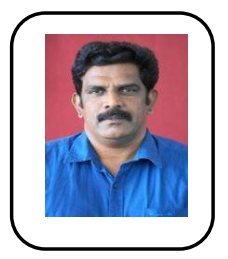

P. Ramesh Babu received the M.E degree from Saranathan College of Engineering, Trichy in 2011 and B.Tech degree from Sastra University, Trichy in 2006. He is currently pursuing Ph.D degree in Anna University, Chennai and working as Assistant Professor in the department of EEE in Saranathan College of Engineering, Trichy. He has 13 years of experience in teaching. He has published papers in International conferences and Journals. His research interest includes Power Electronics and Drives, Electrical Machines, Solar energy conversion systems.

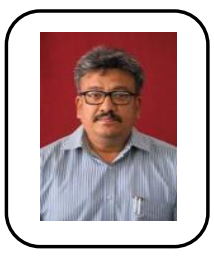

Dr. C. Krishnakumar received Doctorate degree from Anna University, Chennai in 2014 under the stream of Electrical Engineering. He obtained M.Tech degree from Sastra University, Trichy in 2002 and B.E degree from Bharathidasan University, Trichy in 1994. He is currently working as Professor/Head in the department of EEE in Saranathan College of Engineering, Trichy. He has 16 years of experience in teaching and 5 years of industrial experience. He has published papers in reputed Journals and International conferences. His research interest includes High Voltage Engineering, Power Electronics and Drives, Solar energy conversion systems.

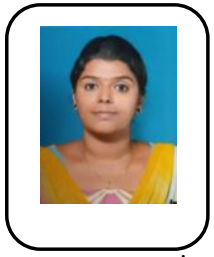

S.Kiruthiga received the B.E degree from Saranathan College of Engineering, Trichy in 2018 and currently pursuing M.E degree in the department of Power Electronics and Drives in Saranathan College of Engineering, Trichy. She has published papers in International conferences and Journals. Her research interest includes Power Electronics and Drives, Solar energy conversion systems.

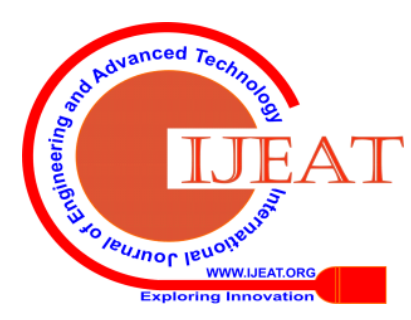

